\title{
Analysis of Students Learning Results by Online-Based Learning in Mathematics Subjects With Two Variable Inequality System Material Class X MIPA 1
}

\begin{tabular}{|c|c|}
\hline \multicolumn{2}{|r|}{$\begin{array}{l}\text { Kasmiati }^{1} \text {, Gusniwati }{ }^{2} \text {, Andi Aras }{ }^{3} \\
1 \text { Institut Agama Islam Negeri Parepare, INDONESIA } \\
2 \text { Institut Agama Islam Negeri Parepare, INDONESIA } \\
3 \text { Institut Agama Islam Negeri Parepare, INDONESIA }\end{array}$} \\
\hline $\begin{array}{l}\text { ARTICLE'S } \\
\text { INFORMATION }\end{array}$ & ABSTRACT \\
\hline $\begin{array}{l}\text { Article history: } \\
\text { Received: Dec-02-2020 } \\
\text { Reviewed: Jan-30-2021 } \\
\text { Accepted: July-29-2021 }\end{array}$ & $\begin{array}{l}\text { Corona Virus Disease } 2019 \text { (Covid-19) has disrupted conventional learning } \\
\text { process. Therefore we need a solution to The challenge. Online learning is one } \\
\text { alternative that can overcome the challenge. So this research was conducted to know } \\
\text { and analyze students' learning results through online learning in mathematics with } \\
\text { the subject of the Two-Variable Inequality System (SPtDV) class X MIPA 1. The } \\
\text { method in this study is the descriptive method with a quantitative approach. The } \\
\text { instrument used was the test instrument on the SPtDV material with a total of } 5 \text { essay } \\
\text { questions. The research sample was } 14 \text { students of class X MIPA } 1 \text { one of the public } \\
\text { high schools in Soppeng Regency. The results of this study were four students with } \\
\text { high scores, six students with moderate grades, and four students with low scores. } \\
\text { Achievement of the lowest percentage of material indicators according to the Level } \\
\text { of Ability to Answer the Problems Correctly of Students in a row from high, medium, } \\
\text { low, namely solving problems in the area of the settlement set on the SPtDV material. } \\
\text { Overall, the achievement of student learning results got a good predicate. }\end{array}$ \\
\hline
\end{tabular}

Corresponding address:

Kasmiati,

E-mail: kasmiatithy@gmail.com

\section{INTRODUCTION}

Corona Virus Disease 2019 (Covid-19) outbreak [1] which has hit 215 countries globally, gives its challenges for educational institutions. To fight Covid-19, the government has forbidden crowds, social restrain and maintain physical distance (physical distancing), wear masks, and always wash hands. Through the Ministry of Education and Culture, the government has banned education activities from carrying out learning to face to face (conventional) and order to conduct online learning. Not a few schools to the university quickly responded to the government's instructions, including SMAN 5 Soppeng, by issuing instruction letters about preventing the spread of Corona Virus Disease (Covid-19) in the school environment. In the circular letter, there are 10 points, and one of them is the recommendation to implement online learning [1]. Online learning has its strength, challenges, and obstacles [1]. To prevent the spread of Covid-19, WHO appeals to stop events that can cause mass crowding. Therefore, face-to-face learning collects many students in the classroom review. The use of digital technology can allow students and teachers to implement the learning process even though they are in different places [2].

The form of learning that can be used as a solution in the Pandemic Covid-19 period is online learning. Online learning uses internet networks with accessibility, connectivity, flexibility, and the ability to bring out various types of learning interactions [3]. The research [4] shows that the use of the internet and multimedia technology can overhaul the way of submission of knowledge and be an 
alternative learning carried out in traditional classes. Online learning can bring students together and lecturers to carry out learning interactions with the help of the internet [5]. At the level of implementation, online learning requires support for mobile devices such as smartphones or Android Phones, Laptops, Computers, Tablets, and iPhones which can be used to access information anytime and anywhere [6]. Universities in the WFH period need to carry out the strengthening of learning online [7]. Learning online has become the demand of the world of education in the last few years [8]. Online learning is needed in learning in the era of Industrial Revolution 4.0 [9].

The use of mobile technology has a large contribution to educational institutions, including achieving distance learning goals [10]. Various media can also be used to support the implementation of learning online. For example, virtual classes use Google Classroom services, Edmodo, and Schoology [11], [12], [13], and instant messaging applications such as WhatsApp [14]. Online learning can even be done through social media such as Facebook and Instagram [15]. Online learning connects students with learning resources (databases, experts/instructors, libraries) that are physically separate or even far apart but can communicate with each other, interact or collaborate (directly / synchronous and indirectly / async Online learning is a form of distance learning that utilizes telecommunications and information technology, for example the Internet, CD-Room [16].

In principle, e-learning is learning that uses services electronics as a tool. In conventional education, the function of e-learning is not to replace but to strengthen traditional learning models. As explained by Cisco regarding the role of e-learning as follows [17]:

1. E-learning is the delivery of information, communication, education, offline or online training.

2. E-learning provides a valuable set of tools for conventional learning (conventional learning models, studies of textbooks, CD-ROMs, and computer-based training) so that they can respond to the challenges of globalization.

3. E-learning does not mean replacing conventional learning models in the classroom but strengthening the model through enrichment of educational content and technology development.

4. Student capacity varies greatly depending on the form of content and method of delivery. Better the alignment between content and tools the transmitter with the learning style, the better the student's capacity, which will give better results.

Ariani and Haryanto said that the use of technology is an absolute necessity in education so that schools become a learning space and a place for students to develop ability optimally and later interact in the middle public [18]. One of the advantages of e-learning is that it can be used as an online test media [19]. Questionnaires can be in the form of correct or incorrect answers, up to the form of a description [20]. Although there are advantages, e-learning also has disadvantages. As in Felix's research, using a qualitative approach is the desire to use it [21]. E-learning has been used for program education [22]. Agus has conducted e-learning evaluation research by asking students about criticism and suggestions for the implementation of learning based on e-learning [23]. In addition, there is also Hanum, who evaluates e-learning evaluasi by using the discrepancy model or other terms gap evaluation program. Hanum uses a quantitative approach that measures program expectations and compares them with the implementation program [24]. That is with [25] different from the two previous people, he evaluated the maturity level of e-learning using the approach e-LMM (e-learning maturity model) where the maturity level is described as five dimensions, namely delivery, planning, definition, management, optimization to ensure that the extent to which the process of developing the use of e-learning media. Besides that, some use the CSE-ECLA model, where the evaluation is carried out from the assessment system until the certification program. 
At present, education is very significant in improving self-quality, similar to the opinion of [26] that education, especially mathematics, can develop student mindset to carry out creative innovations that are useful for their lives. Mathematics is one of the subjects obtained by students from elementary to mid-level education. Class X mathematics subject matter at a high school level is a two-variable system (SPTDV). The SPTDV is a high school material that emphasizes the search for the settlement area of a curve. This makes students assume that SPTDV material is complex and takes a longer time [27].

Mathematics is science regarding the concept of the abstract. Abstract concepts are one of the nature of mathematics. Herman Hudojo suggests that the nature of mathematics is related to ideas, structures, and relationships organized by a logical sequence [28]. It was often said that school mathematics were elements or parts of mathematics chosen or processed to the interests of the education and development of science and technology [29]. This shows that school mathematics is not entirely the same as mathematics as a science. There are differences between school mathematics and mathematics in general.

School math is oriented to the interests of education, namely in the learning process at school. That is, school mathematics is chosen to support the achievement of educational goals or certain mathematics learning. One of the objectives of mathematics learning is to improve the learning result of mathematics.

According to [30], learning result is the indicator of the success of learning, so that it can measure the success or failure of students to receive material from the teacher. If the learning result of minor mathematics, so it can be assumed that students don't master a mathematical material. The frequent students who make mistakes in mathematics work will significantly influence the learning result of mathematics. In addition to the mentioned errors before, mathematics learning results can also be affected by effective aspects. In line with [31], the achievement of mathematics learning results can be caused by internal factors and external factors. Internal students' internal factors include motivation, learning interest, attitudes, affective aspects, and others. As for external factors, such as learning media, infrastructure, and others. Although both the factors above are determinants of whether or not the results of mathematics learning, but the influence of internal factors is more dominating. These factors are the affective aspects or attitudes of students themselves. It is undeniable that many students embedded mindset that mathematics is a difficult lesson to understand, and such views will affect student learning interests. Some experts such as Popham stated that the affective aspect greatly affected cognitive elements [32]. Affective factors are very influential in learning at school.

According to [33], mathematics learns about organized order and structures. Mathematical concepts are arranged hierarchically, structured, and logical, starting from the most straightforward concept to complex ideas, there are topics or concepts of prerequisites as a basis for understanding the next topic or concept so that it requires special and serious handling by teachers as an effort to improve student mathematical learning result.

According to [28], learning changes students' overall behavior and ability after studying, whose form is cognitive, affective, and psychomotor caused by experience and not just one aspect of potential. After a learning process ends, students get a learning outcome. Learning results have an essential role in the learning process. Learning results are used to know what students can understand and understand the material.

According to Mudjiono in [34], learning results are a matter of two sides, namely the side of the student and in terms of the teacher. In terms of students, learning results are a better mental 
development level than the time before learning. The story of mental development is realized in the types of cognitive, affective, and psychomotor realms. Whereas in terms of the teacher, learning results are the completion of the lesson material.

Furthermore, the main indicators of learning results are 1) the absorption of learning materials taught, both individually and in a group [35]. Measurement of this absorption achievement is usually done by determining the minimum completeness criteria (KKM). 2) the behavior outlined in learning objectives has been achieved by students, both individually and in a group.

There has been a lot of research available related to online learning. A study conducted by Astuti, Sari, and Azizah regarding Comparison of Process Effectiveness Learning Using Method ELearning and Conventional, obtained the results that the conventional method (face to face) is still considered better by students than e-learning because it is easier to understand the material and easier to interact with the teacher [36]. However, e-learning itself also has advantages compared to conventional, namely flexibility in lecture time and ease of collecting assignments [36]. Furthermore, research conducted by 1 , which reviewed student self-regulation when participating in online learning, obtained the results that the Furthermore, study conducted by [37], which reviewed student selfregulation when participating in online learning, got the results that students of Mathematics Education FKIP Universitas Riau were able to adapt while taking online classes during the Covid-19 pandemic by having good self-regulation. This study aimed to obtain an overview of online learning in high school, namely an analysis of students' learning results through online learning in mathematics subjects with Two Variable Inequality System material.

\section{METHODS}

The method in this study is the descriptive method with a quantitative approach. Quantitative research methods are one type of research whose specifications are systematic, planned, and structured clearly from the beginning to the design of research design. According to [38], the quantitative research method can be interpreted as based on positivism philosophy, used to examine certain populations or samples. Sampling techniques are generally carried out randomly, data collection using research instruments. This study uses a descriptive approach to describe the object of research or the results of the investigation. According to [38], the descriptive sense is a method that functions to describe or give an image of the object studied through data or samples that have been collected as they are, without carrying out analysis and making generally acumen conclusions.

The instruments used are test instruments. Test instruments in the form of 5 issues of description with SPTDV material. Material indicators in test instruments five questions emphasize the solution to the problem related to the system of two variables.

Data analysis techniques for test instruments on SPTDV material by assessing the achievement of the average student value with the specified weight and then analyzed descriptively. In this study, the author classifies students according to their level of ability to answer questions correctly. To classify it, the author uses the criteria for the attitude of students according to [39], namely:

Table 1. Student Attitude Scale Category Criteria

\begin{tabular}{ll}
\hline \multicolumn{1}{c}{ Score } & Category \\
\hline score $<\bar{x}-\frac{1}{2} s$ & Low \\
$\bar{x}-\frac{1}{2} s \leq$ score $\leq \bar{x}+\frac{1}{2} s$ & Middle \\
score $>\bar{x}+\frac{1}{2} s$ & High \\
\hline
\end{tabular}


Examples of instruments used during this research are presented: Half the first number coupled with twice the second number is 8 . At the same time, two times the first number minus the second number is 6 . The first number plus two times the second number is ...

\section{RESULTS AND DISCUSSION}

The results and discussion of the results of the student classification by the level of ability to answer questions correctly class X MIPA 1 students based on the specified criteria in the table below:

Table 2. Classification of the Student by the Level of Ability

\begin{tabular}{cccc}
\hline \multicolumn{2}{c}{ The Level of Ability to Answer the Questions Correctly by } & \multirow{2}{*}{ Total } \\
& Students & & \\
\cline { 1 - 2 } High & Middle & Low & \\
\hline 4 students & 6 students & 4 students & 14 students \\
\hline
\end{tabular}

Table 2 shows that students with the level of ability to answer questions correctly from five questions with are given. Four students get high scores. This means the level of understanding of the material is quite good. There are six students with moderate ability and four students with low ability levels or below average. Students' knowledge is said to be good if the level is at a high and medium level.

It can be concluded that the average level of ability to answer students' questions is at a moderate level. To improve the ability to answer students' questions. The teacher as a facilitator must provide training for students to answer questions well, students must continue to hone their thinking skills to get better results. Apart from that, students are also able to analyze and evaluate questions.

Apart from the affective aspect factors that affect students' mathematics learning outcomes, other factors influence it. The author explores information by reading research journals, one of which is research journals [39] about the factors that affect student learning outcomes.

1. The background of the student

An indicator for the background is that students come from families capable of in the economy, have good academic achievements in high school, have exemplary academic achievements, always get parental guidance in learning, and live in an environment that encourages them to learn. In accordance with the indicator, it means students can study contextual teaching materials integrating related and realistic knowledge.

2. The interest of students

The indicators for interest are students like mathematics subjects, interested in studying mathematics, always paying attention to mathematics learning well, accepting mathematics teaching well, and actively participating in mathematics learning. In accordance with the indicator, it means students have good interests in studying mathematics.

3. The attitude of the student

Indicator for attitude is grateful for studying because it can learn mathematics well, working with friends when mathematics, trying to consistently use the symbols and terms of mathematics, trying to be disciplined using the rules and formulas of mathematics in resolving mathematical problems, and feeling believing In accordance with these indicators, students have an excellent attitude to study mathematics.

\section{Motivation Students}

Indicators for Motivation are students always trying to find a task answer in various ways, always trying to succeed in doing assignments, having a strong boost in learning mathematics, and always 
creating exciting activities. In accordance with these indicators, it means that students are motivated to study contextual teaching materials integrating related knowledge and realistic.

5. Student learning style

Indicators for learning styles are students easier to understand mathematics by looking, reading, or writing, it is easier to remember mathematics than I do through practice, it is easier to master mathematics after listening to the explanation of the teacher and discussion, preferring to discuss and explain mathematical material, easy to master In accordance with these indicators, it means that the learning style of students supports for the application of contextual teaching materials integrating related knowledge and realistic [40].

In theory, the five factors of the characteristics of the students affect learning results. For this reason, the five factors are regressor variables, and learning results are a variable response. Thus, a linear regression model can be formed. Four students are included in the incomplete category, and ten students are included in the complete category. This shows that there is 71.4 percent of students can answer correctly. The learning result of students can be seen in Table 2:

Table 3. The Learning Result of Students

\begin{tabular}{|c|c|c|c|c|c|c|c|c|}
\hline \multirow{2}{*}{$\begin{array}{l}\text { Students' } \\
\text { Code }\end{array}$} & \multicolumn{5}{|c|}{ Score in Each Question } & \multirow{2}{*}{$\begin{array}{l}\text { Total } \\
\text { Score }\end{array}$} & \multirow{2}{*}{ Information } & \multirow{2}{*}{ Category } \\
\hline & 1 & 2 & 3 & 4 & 5 & & & \\
\hline S1 & 15 & 20 & 20 & 20 & 20 & 95 & Passed & A \\
\hline S2 & 18 & 12 & 15 & 12 & 5 & 62 & Did not pass & $\mathrm{C}$ \\
\hline S3 & 20 & 15 & 15 & 14 & 15 & 79 & Passed & B \\
\hline S4 & 20 & 15 & 15 & 15 & 15 & 80 & Passed & A \\
\hline S5 & 5 & 10 & 13 & 8 & 5 & 41 & Did not pass & $\mathrm{E}$ \\
\hline S6 & 20 & 15 & 15 & 15 & 5 & 70 & Passed & B \\
\hline S7 & 17 & 15 & 14 & 5 & 15 & 66 & Did not pass & $\mathrm{C}$ \\
\hline S8 & 20 & 20 & 20 & 17 & 20 & 97 & Pass & A \\
\hline S9 & 20 & 15 & 15 & 15 & 5 & 70 & Pass & B \\
\hline S10 & 20 & 15 & 15 & 10 & 14 & 74 & Pass & B \\
\hline S11 & 20 & 20 & 10 & 15 & 10 & 75 & Pass & B \\
\hline S12 & 20 & 15 & 15 & 15 & 15 & 80 & Pass & A \\
\hline S13 & 20 & 15 & 15 & 15 & 5 & 70 & Pass & B \\
\hline S14 & 20 & 12 & 17 & 10 & 5 & 64 & Did not pass & $\mathrm{C}$ \\
\hline Rata-Rata & & & & & & 73,07 & & \\
\hline
\end{tabular}

Linear regression models with background regressor variables (L), interest (MI), attitude (s), motivation (MO), learning style $(\mathrm{g})$, and variable response learning result $(\mathrm{H})$. The regression model obtained has not shown a linear relationship between learning results with at least one of the background variables, interests, attitudes, motivations, and learning styles.

1. A linear relationship between learning styles and learning outcomes. Suppose it shows a linear relationship between learning outcomes and learning styles. In this case, learning styles have a statistically significant linear effect on learning outcomes.

2. A linear relationship between learning styles and learning attitudes. Suppose it shows a linear relationship between learning styles and learning attitudes. In this case, learning attitudes have a statistically significant linear effect on learning techniques.

3. A linear relationship between learning attitudes with interest and motivation to learn. Suppose it shows a linear relationship between learning attitudes with interest and motivation to learn. In this case, interest and motivation to learn together have a statistically significant linear effect on learning attitudes. 
4. A linear relationship between interest in learning and student background. Suppose it shows a linear relationship between interest in learning and the experience of students. In this case, the student's experience gives a statistically significant linear effect on interest in learning.

5. A linear relationship between learning motivation and student background. Suppose it shows a linear relationship between learning motivation and student background. In this case, the student's experience gives a statistically significant linear effect on learning motivation.

6. A linear relationship between learning attitudes and student background. Suppose it shows a linear relationship between learning attitudes and students' experiences. In this case, the student's experience gives a statistically significant linear effect on students' learning attitudes.

Based on the relationship described above, learning outcomes are directly influenced by learning styles. Learning styles are directly influenced by learning attitudes but do not directly affect learning outcomes.

Learning attitudes are directly influenced by students' interests and motivation to learn. At the same time, the learning attitude is directly influenced by the background. Together with motivation and interest, the experience does not affect learning attitudes. However, interest and motivation are directly influenced by background. Students who have a good experience of interests, attitudes, motivation, and learning styles will produce good learning achievements and are supported by the environment in which they live. Thus, some factors directly affect learning outcomes, and some factors are basic factors that support the emergence of other factors.

\section{CONCLUSIONS AND SUGGESTIONS}

Analysis of students' learning results through online learning in mathematics subjects with class X MIPA 1 Senior High School Soppeng SPTDV material. To improve student learning results, selecting methods and the right way of teaching and matching the conditions of the students we teach greatly help the teaching and learning process. The factors that can inhibit student learning results include backgrounds, interests, attitudes, motivation, and learning styles. Therefore, selecting proper methods can increase students' activity, understanding, and focus on the material taught and provide experience thinking about the concepts given.

\section{ACKNOWLEDGEMENT}

Thanks to:

1. To both parents of the author as a source of life, the main supervisor of the author. They have raised, educated, and gave the author's opportunity to continue their education to college. Both have a very important role. So it feels thank you will never be enough to describe the form of awards to both parents.

2. Mr. Dr. Ahmad Sultra Rustan M.Sc., as the Chancellor of the State Islamic Institute (IAIN) Parepare.

3. All lecturers are given the knowledge given to the author while undergoing a lecture process.

4. Mrs. Syamsiah R. S.Pd is a civil servant teacher who has taken the time to teach and guide and assist the author in overcoming the author's difficulties.

5. Teachers and staff of Soppeng 5 Public High School for Help and Cooperation. SMAN 5 SOPPENG students are especially supported by class X MIPA 1, which have collaborated in the process of this research to improve education in Soppeng 5 Public High School in particular and the city of Soppeng and the nation and the nation in general. 
6. The class X MIPA 1 SMA Negeri 5 Soppeng, that have collaborated in this research process to improve education in SMA NEGERI 5 SOPPENG in particular and the city of Soppeng and the Nation and State in general.

7. Dra. Hj. Fatmawati, M.Pd as the Head of UPT SMA NEGERI 5 SOPPENG, has given the author permission and the opportunity to conduct research.

8. Friends who also conducted research at SMAN 5 Soppeng which had provided moral support and contributions to the success of this study.

9. All parties who participate in support, help and participate which cannot be included one by one, so that the research conducted in Soppeng 5 Public High School can be carried out properly.

\section{REFERENCE}

[1] A. R. Yandwiputra, "Kuliah Jarak Jauh karena Virus Corona, UI: Bukan Lockdown," 2020. [Online]. Available: https://metro.tempo.co/read/1319537/kuliah-jarak-jauh-karena-viruscorona-ui-bukan-lockdown. [Accessed: 03-Nov-2020].

[2] N. B. Milman, "Distance Education," in International Encyclopedia of the Social \& Behavioral Sciences 2nd Edition, Elsevier, 2015, pp. 567-570.

[3] J. L. Moore, C. Dickson-Deane, and K. Galyen, "E-Learning, online learning, and distance learning environments: Are they the same?," Internet High. Educ., vol. 14, no. 2, pp. 129-135, 2011.

[4] D. Zhang, J. L. Zhao, L. Zhou, and J. F. Nunamaker, "Can e-learning replace classroom learning?," Commun. $A C M$, vol. 47, no. 5, pp. 75-79, 2004.

[5] E. Kuntarto, "Keefektifan Model Pembelajaran Daring Dalam Perkuliahan Bahasa Indonesia di Perguruan tinggi," J. Indones. Lang. Educ. Lit., vol. 3, no. 1, pp. 99-110, 2017.

[6] J. Gikas and M. M. Grant, "Mobile Computing Devices in Higher Education: Student Perspectives on Learning with Cellphones, Smartphones \& Social Media," Internet High. Educ., vol. 19, pp. 18-26, 2013.

[7] W. Darmalaksana, R. Y. A. Hambali, A. Masrur, and Muhlas, "Analisis Pembelajaran Online Masa WFH Pandemic Covid-19 sebagai Tantangan Pemimpin Digital Abad 21," Karya Tulis Ilm. Masa Work. From Home Covid-19 UIN Sunan Gunung Djati Bandung Tahun 2020, vol. 1, no. 1, pp. 1-12, 2020.

[8] W. He, G. Xu, and S. E. Kruck, "Online is education for the 21st century," J. Inf. Syst. Educ., vol. 25, no. 2, pp. 101-105, 2014.

[9] R. Andrianto Pangondian, P. Insap Santosa, and E. Nugroho, "Faktor - Faktor Yang Mempengaruhi Kesuksesan Pembelajaran Daring Dalam Revolusi Industri 4.0," in Seminar Nasional Teknologi Komputer \& Sains (S AINTEKS), 2019, pp. 56-60.

[10] A. T. Korucu and A. Alkan, "Differences between m-learning (mobile learning) and e-learning, basic terminology and usage of m-learning in education," in Procedia - Social and Bebavioral Sciences, 2011, vol. 15, pp. 1925-1930.

[11] M. A. S. Enriquez, "Students' Perceptions on the Effectiveness of the Use of Edmodo as a Supplementary Tool for Learning," DLSU Res. Congr., pp. 6-11, 2014.

[12] A. S. Sicat and M. Ed, "Enhancing College Students' Proficiency in Business Writing Via Schoology," Int. J. Educ. Res., vol. 3, no. 1, pp. 159-178, 2015.

[13] Shampa Iftakhar, "Google Classroom: What Works and How?," J. Educ. Soc. Sci., vol. 3, no. 2, pp. 12-18, 2016.

[14] S. So, "Mobile instant messaging support for teaching and learning in higher education," Internet High. Educ., vol. 31, pp. 32-42, 2016.

[15] V. Kumar and P. Nanda, "Social Media in Higher Education," Int. J. Inf. Commun. Technol. Educ., vol. 15, no. 1, pp. 97-108, 2018.

[16] R. Heinich, M. Molenda, J. Russell, and S. Smaldino, Instructional Media and Technologies for 
Learning (7th ed.). Englewood Cliffs, NJ: Prentice Hall, 2001.

[17] M. Yazdi, "E-Leraning Sebagai Media Pembelajaran Interaktif Berbasis Teknologi Informasi," J. Ilm. Foristek, vol. 2, no. 1, pp. 143-152, 2012.

[18] T. Ismiasri, Ariani and Haryanto (in Ismiasri, 2011:128) said that the use of technology is an absolute necessity in the world of education so that schools really become a learning space and a place for students to develop ability optimally, and later can interact in . Blitar: STKIP, 2011.

[19] R. U. C. Rolisca and B. N. Achadiyah, "Pengembagnan Media Evaluasai Pembelajaran dalam Bentuk Online Berbasis ELearning Menggunakan Software Wondershare Quiz Creator Dalam Mata Pelajaran Akuntansi SMA Brawijaya Smart School (BSS)," J. Pendidik. Akunt. Indones., vol. 12, no. 2, pp. 41-48, 2014.

[20] Y. Yamasari, "Fasilitas Evaluasi yang Menggabungkan Pengukuran, Bimbingan dan Penilaian dalam Sistem e- Learning," J. Penelit. Pendidik. Mat. Dan Sains, vol. 15, no. 1, 2008.

[21] Felix and A. R. Wirawan, "Evaluasi Penerapan E-Learning Di Jurusan Akuntansi Fakultas Bisnis dan Ekonomika Universitas Surabaya.," Calyptra J. Ilm. Mhs. Univ. Surabaya, vol. 3, no. 2, pp. 1-14, 2014.

[22] S. Pudjo Suparto, "Evaluasi Program E-Learning Bagi Petugas Lapangan," J. Cakrawala Pendidik., vol. 31, no. 1, pp. 112-128, 2012.

[23] A. Sutedjo, "Implementasi dan Evaluasi Pembelajaran E-Learning Pada Mata Kuliah Geografi Transportasi dan Komunikasi Mahasiswa yang Memprogram di Semester Gasal Tahun Akademik 2012/2013," J. Geogr., vol. 11, no. 21, pp. 51-63, 2013.

[24] Numiek Sulistyo Hanum, "Keefektifan E-Learning sebagai Media Pembelajaran (Studi Evaluasi Model Pembelajaran E-Learning SMK Telkom Sandhy Putra Purwokerto)," J. Pendidik. Vokasi, vol. 3, no. 1, pp. 90-102, 2013.

[25] E. Tutut Usahen, Fahmi Rizal, "Evaluasi Tingkat Kematangan E-Learning Berdasarkan ELearning Maturity Model (eMM) Di Universitas Riau," J. Pendidikan, Teknol. dan Kejuru., 2013.

[26] A. S. Purwandari, M. D. Astuti, and A. Yuliani, "Evaluasi Kemampuan Komunikasi Matematis Siswa SMP Pada Materi Sistem Persamaan Linear Dua Variabel," IndoMath Indones. Math. Educ., vol. 1, no. 1, pp. 55-62, 2018.

[27] N. R. Sari, W. Hidayat, and A. Yuliani, "Analisis Hasil Belajar Matematika Siswa Kelas X SMA Pada Materi SPLTV Ditinjau Dari Self-Efficacy,” UNION J. Ilm. Pendidik. Mat., vol. 7, no. 1, pp. 93-104, 2019.

[28] H. Hudojo, Pengembangan Kurikulum dan Pembelajaran Matematika. Malang: Universitas Negeri Malang, 2005.

[29] R. Soedjadi, Kiat Pendidikan Matematika di Indonesia; Konstatasi Keadaan Masa Kini Menuju Harapan Masa Depan. Jakarta: Dirjen Dikti Depdiknas, 2000.

[30] F. Irwanti and S. A. Widodo, "Efektivitas STAD terhadap hasil belajar matematika ditinjau dari minat belajar siswa kelas VII," Pros. Semin. Nas. Pendidik. Mat. Etnomatnesia, vol. 1, no. 2, pp. 927-935, 2018.

[31] H. Suhendri, "Pengaruh Kecerdasan Matematis-Logis dan Kemandirian Belajar tehadap Hasil Belajar Matematika," J. Form., vol. 1, no. 1, pp. 29-39, 2011.

[32] A. Hidayad, Masrukan, and Kartono, "Instrumen Asesmen Sikap Siswa Berbasis Konservasi pada Pembelajaran Matematika SMP,” J. Res. Educ. Res. Eval., vol. 6, no. 1, pp. 30-38, 2017.

[33] E. Suwangsih, Model Pembelajaran Matematika. Bandung: UPI Press, 2006.

[34] Dimyati and Mudjiono, Belajar dan Pembelajaran. Jakarta: Rineka Cipta, 2006.

[35] S. B. Djamarah and A. Zain, Strategi Belajar Mengajar. Jakarta: Rineka Cipta, 2006.

[36] C. C. Astuti, H. M. K. Sari, and N. L. Azizah, "Perbandingan Efektifitas Proses Pembelajaran Menggunakan Metode E-Learning dan Konvensional,” Proc. ICECRS, vol. 2, no. 1, pp. 35-39, 2019.

[37] H. M. Siregar and S. N. Siregar, "Profil Self Regulation Mahasiswa Pendidikan Matematika FKIP Universitas Riau di Masa Pandemi Covid-19," ANARGYA J. Ilm. Pendidik. Mat., vol. 4, no. 1, pp. 1-10, 2021. 
[38] Sugiyono, Metode Penelitian Pendidikan (Pendekatan Kuantitatif, Kualitatif, dan R\&D). Bandung: Alfabeta, 2012.

[39] S. Azwar, Penyusunan Skala Psikologi. Yogyakarta: Pustaka Pelajar, 2012.

[40] Helma and Edizon, "Faktor-Faktor yang Mempengaruhi Hasil Belajar Matematika Siswa Untuk Penerapan Bahan Ajar Kontekstual Mengintegrasikan Pengetahuan Terkait dan Realistik," J. EKS AKTA Pendidik., vol. 1, no. 1, pp. 86-92, 2017.

\section{BIOGRAPHY}

Kasmiati

She was born in Soppeng on October 15, 1998. Now she is a student in the Tadris Matematika S1 program at the Institut Agama Islam Negeri ParePare. Phone number 085298313618 and email: kasmiatithy@gmail.com

Gusniwati

Lecturer in the Institut Agama Islam Negeri ParePare. He obtained his Strata-2 (S2) in Universitas Tadulako. Email: gusniwati@iainpare.ac.id

Andi Aras

Lecturer in the Institut Agama Islam Negeri ParePare. He obtained his Strata-2 (S2) in Universitas Negeri Makassar. Email: aras9math@gmail.com 